\title{
Examination of Preschool Teachers' Views on Sexuality Education
}

\author{
Esra Ünlüier \\ Department of Preschool Education, Kocaeli University, Kocaeli, Turkey
}

Copyright $\mathrm{C} 2018$ by authors, all rights reserved. Authors agree that this article remains permanently open access under the terms of the Creative Commons Attribution License 4.0 International License

\begin{abstract}
The aim of the study is to examine the knowledge and the information sources of preschool teachers about sexuality education, sexual behaviours that they confront in the preschool classes and their reactions to these behaviours. The research was designed according to the qualitative method. Semi-structured interviews were conducted with 8 volunteer schoolmistresses with at least 3 years of professional experience. The semi-structured interview form was prepared by considering sexuality education, sexual behaviours confronted in preschool classes and the dimensions of their reaction to these behaviours. The data acquired in the study were coded and classified by content analysis method. As a result of research, the teachers participating in the research stated that they did not take any course under the name of sex instruction during their teacher training. Within the teachers' definition of sexuality education, there are informative lessons such as knowing his/her own gender, gender identity development, learning to protect his/her own body and informing about reproduction. Not to find their knowledge about sexuality education adequate, the teachers participating the research stated that they abstain from scheduling activities related to sexuality education. Teachers pointed out that they confront verbal sexuality frequently and gender identity games rarely in their classes. Besides, they stated that they appeal to solutions such as connivance, distraction, involvement to their games, warning and referring to counselling service in the face of such possible sexual behavior (touching inappropriate with adult, sexual game, masturbation, verbal sexuality, gender identity games) within the class.
\end{abstract}

Keywords Preschool Education, Preschool Teachers, Sexuality Education

\section{Introduction}

In many societies, sexuality concept was ascribed to adolescence period and kept away from early childhood. It was scarcely dealt with the matter of sexuality also in the literature of child development. As a result of this situation, it is quite misleading to think that the child's feelings and thoughts about sexuality do not develop. Sexuality does not appear suddenly in adolescence period, it begins from the moment the baby comes into the world (Pernould [15]; Lewis [13]) and increases in preschool years with increasing questioning and curiosity (Smith, [17]). When children in early childhood period are observed, it is seen that sexuality exists in children in various forms. The child knows that he/she belongs to a gender, he/she is in sexual curiosity and acts in accordance with his/her gender (Eker [6]).

Another mistake about sexuality is to think that if sexuality education is given in early years, the children will begin a sex life and their innocence will be impaired (Noonan, 1999). The reason of this mistake is the truth that most of the people think that sexuality education covers only teaching sexual behaviours. However, sexuality education is not limited to this. Sexuality education is to give insight to the children about emotions, attitudes, communication, giving a decision, other personal skills and knowledge in order to help them to be sexually healthy individuals (SIECUS [16]).

Although all the teachers need much more information about how to approach the subject and link it with developmental period, most of the preschool teachers have limited information about sex development (Cahill and Theilheimer [3]). In their study conducted with the teachers, Chrisman and Couchenour (1997) revealed that even the preschool teachers who took many courses about child development did not take any formal education or course about sex development of children (Chrisman and Couchenour [4]). For this reason, an important part of sexuality education is given informally (Lenderyou [12]).

When the preschool education program in our country is examined, it's seen that the concept of "sexuality education $"$ is underestimated in the program. When the program is glanced, it will be seen that the word of "sexual" is mentioned only in page 48, under the title of "Occupational Ethics and Teacher Efficiency" and worded as follows, 
"...physical, sexual, verbal and emotional abuse...". No other sentence related to sexuality education was found. (Çalışandemir, Bencik \& Artan, [5]). Within the context of teacher education program, there is no compulsory course under the name of sexuality education, it appears in several programs as optional (none/program). In Turkey, it's seen that most of the researches related to sexuality education during the early childhood are done with parents, while the studies conducted with teachers are limited.

\section{Problem Status}

The aim of this research is to examine the views of the preschool teachers on sexuality education. In accordance with this general purpose, an answer was sought for the following research questions:

1. What are the opinions of preschool teachers about their knowledge and their sources of information related to sexuality education?

2. What are the sexual behaviours that teachers encounter in their preschool classrooms?

3. What are the reactions of the teachers to 6 scenarios related to possible sexual behaviours in preschool classrooms?

\section{Materials and Methods}

\subsection{Research Design}

Research is basically a qualitative study. In this study, interview technique was used as data collection method.

\subsection{The Study Group}

Criterion sampling which is one of the purposive sampling methods has been used in the research. The purposive sampling method, which emerged in the tradition of qualitative research methodology, allows in-depth analysis of the situations thought to have rich information (Yıldırım \& Şimşek [23]). In the criterion sampling method, the criteria considered to be important for selection are determined. The sample selected according to these criteria is considered to represent the population with all their qualities (Tavşancıl and Aslan [19]). While selecting the teachers participating in this research, to work in preschool institutions, to have at least 3 years of professional experience and to be a schoolmistress were determined as the key criterion.

The study group was selected from the teachers serving in both public and private preschool institutions located in Başiskele district of Kocaeli province. The administrators of these public and private preschool institutions located in Başiskele district were informed about the study and they were asked to list the teachers working in their institutions who were volunteer for the interview. The interviews of the research were conducted with 8 volunteer schoolmistress having at least 3 years of professional experience. The study group was limited to 8 people in order to conduct a thorough research by detailed interviews. The names of the teachers in the study group were changed in accordance with the research ethics. For this reason, the teachers were entitled with the following code names, Teacher Asli, Teacher Burcu, Teacher Seda, Teacher Yeşim, Teacher Şeyma, Teacher Ece, Teacher Gizem and Teacher Kübra. The average age of the participants was 35 . The characteristics of the participants are given in Table 1.

Table 1. Demographic Data of the Study Group

\begin{tabular}{|c|c|c|}
\hline Teachers & Professional Experience & Type of School \\
\hline Burcu & 12 & Privacy \\
\hline Asl1 & 5 & Privacy \\
\hline Seda & 10 & State \\
\hline Şeyma & 8 & State \\
\hline Kübra & 15 & State \\
\hline Yeşim & 13 & State \\
\hline Ece & 11 & Privacy \\
\hline Gizem & 8 & Privacy \\
\hline
\end{tabular}

\subsection{Data Collection}

The data of the research were acquired through interviews covering the interview forms consisted of the semi-structured questions. In semi-structured interviews, the participants are asked questions that are prepared in advance. However, new questions may be asked if necessary or some questions can be cancelled (Yıldırım and Şimşek [23]). In this study, which was conducted by qualitative research method, the research data were obtained from interviews conducted with 8 volunteer teachers in the spring semester of 2017-2018 school year. While preparing the interview form used in the research, a literature review was made in accordance with the aim of the research. After the literature review, the questions of the first two parts of the Semi-Structured Interview Form were formed and the scenarios related to the possible sexual behaviours in the preschool classes listed in section three were built by interviewing 24 preschool teachers. The Semi-Structured Interview Form was presented to 4 experts working in the fields of preschool teaching and psychological counselling and guidance in order to evaluate the purpose of the study and its suitability for the qualitative study. An expert evaluation form was formed to enable the experts to evaluate the form. For each question in this form, "good", "fair" and "poor" categories were arranged. After the expert evaluation, the Semi-Structured Interview Form was finalized. A pilot interview was conducted after the expert opinion. In this interview, the comprehensibility of the form was evaluated and used after making the necessary 
amendments. Under the light of the feedback received from the experts and a pilot scheme conducted, the questionnaire form was revised and finalized The first part of the interview form consists of questions about teachers' knowledge and information sources about sexuality education, the second part, questions about the sexual behaviours that teachers encounter in the preschool classes, and the last part consists of questions about 6 scenarios related to possible sexual behaviours that may be experienced in preschool classes. In order to determine the scenarios in the last section, the interviews were conducted with 24 preschool teachers. As a result of these interviews, the sexual behaviours that the teachers encounter in the preschool classes were grouped under 5 titles by considering the study about grouping of sexual behaviours in the home and school environment studied by Larsson and Svedin [11]). These titles are: 1) touching inappropriate with adult, 2) sexual game, 3) masturbation, 4) verbal sexuality and (5) gender identity games.

The researcher interviewed the participants face to face and the interviews were recorded with a tape recorder by the permission of the participants. After the interviews, the recorded data were converted to written texts. These written texts were given to the participants and the participants were asked to verify that these written texts were accurate and complete. Thus, the reliability of the data is provided. In accordance with the Interview Form prepared by the researcher, the interviews were conducted within a period of $60-90$ minutes on the date of 28 March-19 April. The interview technique was selected to be effective on collecting data related to experiences, attitudes, opinions, complaints, emotions and beliefs of the individuals (Briggs, [1]). The questions were asked to the interviewees in the same order. There was no limitation in the answers of the interviewees. Thus, teachers were given the opportunity to explain the ideas they considered important. A week before the interview with the teachers, the date and time of the interview were determined. The interviews were conducted in the schools where the teachers work, in the places determined by the administrators of the schools. At the beginning of the interviews, the demographic characteristics of the participants were noted.

\subsection{Analysis of Data}

Content analysis method was used in analysis of data. The content analysis method is defined as a systematic, repeatable technique in which some words of a text are summarized with smaller content categories, based on specific rules-based encodings. (Büyüköztürk et al. [2]). The raw data obtained from the interviews were coded and the certain categories were determined in this direction. The data were classified under these categories and made meaningful for the reader. Coding and categorization process had been conducted by the researcher as repetitive. Thus, unnecessary encodings were removed and new codes were added to the required parts by adhering to the problem and purpose of the research.

\section{Conclusions}

The results obtained from this research were examined under three categories consisting of preschool teachers' knowledge and information sources about sexuality education, sexual behaviours that they encounter in the preschool classes and their reactions to 6 scenarios about the possible sexual behaviours in the preschool classes.

\subsection{Results on Knowledge Levels and Information Sources of the Preschool Teachers about Sexuality Education}

\subsubsection{The results Related to the Question of what is Sexuality Education?}

"What is sexuality education?" question was asked to the preschool teachers participated in the research. The answers given by the teachers to the question of what is sexuality education is shown in Table 2 .

Table 2. Sexuality Education Definition of Preschool Teachers

\begin{tabular}{|c|c|}
\hline What is sexuality education? & $\mathrm{f}$ \\
\hline knowing his/her gender & 8 \\
\hline sexual identity development & 8 \\
\hline learning how to protect his/her body & 8 \\
\hline information about reproduction. & 2 \\
\hline
\end{tabular}

When Table 2 is examined, it's seen that for the teachers participating in the research, sexuality education means knowing his/her gender, sexual identity development, learning how to protect his/her body and reproduction.

\subsubsection{The Results Related to Informal Sexuality Education}

The preschool teachers participating the research were asked these following questions: "From whom did you take your first sexuality education?", "Do you think the training you took is adequate?", "What does your training include?" and "Do you think that the content of the training you receive is related to being a woman?". 6 teachers stated that they took their first sexuality education from their mothers and 2 of them from another woman in their family (such as aunt, grandmother), they stated that the sexuality education they took was inadequate and limited with the information to protect their bodies from the opposite sex.

"Sit down after you smooth your skirt, do not show your body. You are a girl, that's why you should be more careful while sitting down." Teacher Burcu. 
"When I was in primary school, I had nakedly entered the room where my father was in. I remember that my mother and aunt-in-law had spoken to me related to this matter, not my father. You are a girl, you should be careful. They told me not to take off my clothes near anyone and to hide my body." Teacher Aslı

"I was always warned by my mother to watch my skirt while sitting down and standing up. All my knowledge about sexuality comes from my friends. I still find my parents inadequate..." Teacher Şeyma

All of the teachers participating in the research think that the content of sexuality education received from their families is related to being women. Teacher Şeyma, Teacher Aslı and Teacher Kübra stated that they have brothers, they were always warned by their families about protecting their bodies, while their brothers were not warned like that.

"For being a girl, to hide my body was frequently reminded by my family." Teacher Seda

"You are a girl..." Teacher Burcu, Asll, Yeşim and Gizem

"Your brother is a male..." Teacher Şeyma, Teacher Aslı and Teacher Kübra

\subsubsection{The Results Related to Formal Sexuality Education}

The question of "Did you take any course related to sexuality education in your teacher training?" was asked to the teachers. The teachers stated that they did not take any sexuality education in their teacher trainings, but they took in-comprehensive trainings during their child development and maternal and infant health lectures.

The question of "Have you received any in-service training on sexuality education during your teaching?" was asked to the teachers. Only two of the teachers participating the research (Teacher Ece and Gizem) stated that they took in-service training on sexuality education in early childhood. It was seen that the content of this in-service training taken by the teachers was limited to teaching the children how to protect their bodies.

"After the increase of sexual abuse in recent years, it was an informative training given by our school counsellor about how the children cannot protect their bodies." Teacher Ece

\subsubsection{The Results Related to Sexuality Education in the Preschool Programs}

The question of "Is there any special activity about sexuality education in your program?" was asked to the teachers. Teachers participating in the research do not find their knowledge on sexuality education as adequate. They stated that because of that reason, they abstain from planning any special activity related to sexuality education in their program. But four of the teachers (Teacher Asl,
Teacher Burcu, Teacher Ece and Teacher Gizem) stated that in case of need, they planned activities together with the counselling service in particular. All other teachers, except for Burcu and Ece, think that an activity related to sexuality education will attract children's attention more if there is no question from children or any relevant need.

\section{"I plan a sexuality education for children when there is an increase in children's verbal sexuality or sexual play behaviours" Teacher Gizem}

"It will be like the term, "Let the sleeping dogs lie." The child who does not have any thoughts about sexuality on his/her mind will be curious after such a training and behave improperly to see the body of his/her friends..." Teacher Yeşim

"Since this age group is very curious, they will ask more questions to learn more about the information we give, this may cause negative reactions from families. He/she had no curiosity before, it had increased too much, they may say" Teacher Kübra

\subsection{The Results Related to Sexual Behaviours that Teachers Encounter in Preschool Classrooms}

Teachers were asked about the sexual behaviours they encountered in preschool classes during their teaching experiences. The behaviours stated by the teachers were coded under the grouping of sexual behaviour in the home and school environment by Larsson and Svedin [11]). According to the teachers participating in the research, the prevalence of these behaviours in the classroom is given in

Table 3. Prevalence of Teachers Encountering Sexual Behaviour in Preschool Classes

\begin{tabular}{|c|c|c|c|}
\hline \multirow{2}{*}{\begin{tabular}{c} 
Sexual behaviour \\
\cline { 2 - 4 }
\end{tabular}} & usually & often & seldom \\
\hline $\begin{array}{c}\text { touching inappropriate with } \\
\text { adult }\end{array}$ & 4 & $\mathrm{f}$ & $\mathrm{f}$ \\
\hline sexual game & 1 & 3 & 2 \\
\hline masturbation & 1 & 5 & 1 \\
\hline verbal sexuality & 8 & - & - \\
\hline gender identity games & 8 & - & - \\
\hline
\end{tabular}

The teachers participating in the research stated that sexual events that are categorized in 5 groups (touching inappropriate with adult, sexual game, masturbation, verbal sexuality and gender identity games) were being observed differently in their classrooms each year. Teachers stated that one or two children masturbate each year in their classes and that boys sometimes behave in a way that does not fit the adult. It had been observed by the teachers that the games or the questions of the children, who had somebody around them being pregnant or giving birth recently (such as mother or aunt) increased. Teachers stated that behaviours and plays towards sexual identity 
were seen especially in dramatic games and most frequently they encountered verbal sexuality in their classes.

"At the time of swimming lessons, dressing and undressing together, there was an increase in the words of butt and weenie." Teacher Aslı

"Almost every year, there is one or two masturbating children in my class..." Teacher Gizem and Aslı

"Most of the children start to laugh when they hear the words such as butt and weenie..." Teacher Kübra

"The children, whose mothers are new-pregnant or new mother, reflect this situation by placing pillows on their belly, I observe this situation very much in children who are the only children of the family." Teacher Şeyma

\subsection{The Results Related to the Reactions of the Teachers}

To the 6 Scenarios about the Possible Sexual Behaviours in Preschool Classrooms

The teachers were given 6 scenarios related to possible sexual behaviours in their classes and their reactions to these behaviours in that scenario were asked. The answers given by the teachers were grouped under 5 categories. In Table 4, the reactions of the teachers were given.

Teachers participating in the research stated that they choose to ignore, to distract, to involve their games, to warn or to send counselling service in the presence of possible sexual behaviours (touching inappropriate with adult, sexual game, masturbation, verbal sexuality, gender identity games) in their classes. It's seen that the teachers mostly preferred to distract or to ignore these behaviours, unless others were harmed. The teachers who stated that they would send to the counselling service had counselling services in their schools and they used this method as an additional one to distraction method. In cases where there is a possibility of harm to others, two teachers stated that they might verbally warn.

"When I see a masturbating child inside the class, I try to distract him, I observe his/her behaviour when it occurs. In addition to this, I send him/her to counselling service." Teacher Ece

"When they use sexual words, I instantly response. I warn them about being careful what they say and after that I absolutely talk with them about this behaviour." Teacher Yeşim

"When I see any children playing out of my view the game to be a doctor and touching or looking to their private body parts, I absolutely go near them and ask if I can learn what they play and if they allow me to involve their games." Teacher Seda

\section{Discussion and Suggestions}

In this study, the teachers stated that they took the first sexuality education from their families, that this sexuality education they took from their families was inadequate, their families abstained from talking about this issue and they were warned to protect their bodies continuously because they were women. In our country, in the studies examining the views of the families about sexuality education, it's seen that most of the parents had insufficient and inaccurate information about the sexual development and the education of the child, that they think the sexuality education should be given during the high school period and they were be shamed speaking about this issue (Eliküçük and Sönmez, [8]; Tuğrul and Artan [20]; Tuzcuoğlu and Tuzcuoğlu [21]). Similarly, in studies conducted abroad, it was observed that families stopped talking after a short speech with their children about sexuality or abstained from talking (Stone, Ingham \& Gibbins [18]; Frankham [10]; Larsson and Svedin [11]).

Tablo 4. Teachers' Reactions to the Sexual Behaviours

\begin{tabular}{|c|c|c|c|c|c|}
\hline \multirow{3}{*}{ Reactions } & \multicolumn{5}{|c|}{ Sexual behaviours } \\
\hline & $\begin{array}{c}\text { touching } \\
\text { inappropriate with } \\
\text { adult } \\
\end{array}$ & sexual game & masturbation & verbal sexuality & $\begin{array}{c}\text { gender identity } \\
\text { games }\end{array}$ \\
\hline & $\mathrm{f}$ & $\mathrm{f}$ & $\mathrm{f}$ & $\mathrm{f}$ & $\mathrm{f}$ \\
\hline to ignore & 1 & 1 & 1 & 3 & 5 \\
\hline to distract & 6 & 4 & 8 & 3 & - \\
\hline to involve their games & - & 2 & - & - & 3 \\
\hline to warn & 2 & 1 & 1 & 2 & - \\
\hline send counselling service & - & - & 3 & - & - \\
\hline
\end{tabular}


The teachers participated in the study stated that they did not take any lecture or in-service training under the name of sexuality education during their teachership education or the period they work as a teacher. 2 of the teachers stated that after the news about child sexual abuse increased in media, an in-service-training was conducted by their counselling service to teach the children how to protect their bodies. The reason that the teachers find themselves insufficient about sexuality education and think that talking about sexuality will attract their attention to this issue and their sexual behaviour will increase causes them to abstain from the sexuality education activities. Therefore, the contribution of school and teacher in the sexuality education of children in early childhood is significantly lower (Elias and Gebhard [6]). For that reason teachers have to be strengthened by additional training programs about sexuality.

It has been observed in many studies that sexual behaviours are common in early childhood (Essa and Murray [8] ). The teachers participating in the research stated that sexual events that are categorized in 5 groups (touching inappropriate with adult, sexual game, masturbation, verbal sexuality and gender identity games) were being observed differently in their classrooms each year. It's seen that the teachers' reactions to the scenarios related to the possible sexual behaviours in their classes were ignoring, distracting, involving their games, warning them and sending them to the counselling service. In the studies conducted in our country, it's seen that preschool teachers have insufficient knowledge about sexual behaviours and they prefer to ignore in the presence of these behaviours (Yeşilay \& Akbaba Altun [22]).

According to the results of the research, addition of sexuality education lessons to preschool teacher education programs, conducting of in-service trainings related to sexuality education for currently working teachers and informing the families about sexuality education through social studies are recommended. Current research is limited to the teacher's views about sexuality education. Further research is recommended for professionals, on teacher's guidance about what to do and/or how to teach children's sexuality education.

\section{REFERENCES}

[1] Briggs, C. L. Learning how to ask: A sociolinguistic appraisal of the role of the interview in social science research (Vol. 1). Cambridge University Press., 1986.

[2] Büyüköztürk, Ş., ÇAKMAK, EK, Akgün, Ö. E., Karadeniz, Ş. Ve Demirel, F. Bilimsel.Araştırma Yöntemleri, Pegem Akademi, Ankara, 2012.

[3] Cahill, B. J., Theilheimer, R. Stonewall in the housekeeping area: Gay and lesbian issues in the early childhood classroom. Queering elementary education: Advancing the dialogue about sexualities and schooling, 39-48, 1999.

[4] Chrisman, K., Couchenour, D. Healthy sexuality development. Washington, DC: National Association for the Education of Young Children, 2002.

[5] Çalışandemir, F., Bencik, S., Artan, İ. Çocukların cinsel eğitimi: geçmişten günümüze bir bakış. Eğitim ve Bilim, 33 (150), 2010.

[6] Eker, E. Cinsel eğitim. Yaşadıç̧a Eğitim Dergisi, 8-10, 1992.

[7] Elias, J., Gebhard, P. Sexuality and sexual learning in childhood. The Phi Delta Kappan, 50(7), 401-405, 1969.

[8] Eliküçük, A., Sönmez, S. 6 yaş çocuklarının cinsel gelişim ve eğitimiyle ilgili ebeveyn görüşlerinin incelenmesi. Sosyal Politika Çalışmaları Dergisi, 25(25), 2011.

[9] Essa, E. L., Murray, C. I. Sexual play: When should you be concerned?. Childhood Education, 75(4), 231-234, 1999.

[10] Frankham, J. Sexual antimonies and parent/child sex education: Learning from foreclosure. Sexualities, 9(2), 236-254, 2006.

[11] Larsson I.B., Svedin C.G. Teachers' and parents' reports on 3- to 6-year- old children's sexual behavior - a comparison. Child Abuse \& Neglect 26: 247-266, 2002.

[12] Lenderyou, G. Sex education in Holland, Ireland, Sweden and the United Kingdom. Social Science Teacher, 21, 19, 1991.

[13] Lewis, M. Early sex role behavior and school age adjustment. Masculinity/femininity: Basic perspectives, 202-226, 1987.

[14] Noonan, R. J. Director of sex questl the sex institute, assessing right-wing opposition to sex education. In IV. World Congress of Sexology in the Plenary Session, 1999.

[15] Pernoud, L., Denizyaran, K. Çocuğun cinsel eğitimi. E Yayınları, 1987.

[16] SIECUS The truth about adolescent sexuality. New York: Sexuality Information and Education Council of the United States, 2003.

[17] Smith, M. Pediatric sexuality: promoting normal sexual development in children. The Nurse practitioner, 18(8), 37-8, 1993.

[18] Stone, N., Ingham, R., Gibbins, K. 'Where do babies come from?'Barriers to early sexuality communication between parents and young children. Sex Education, 13(2), 228-240, 2013.

[19] Tavşancıl, E., Aslan, E. İçerik analizi ve uygulama örnekleri. İstanbul: Epsilon Yayıncılık, 2001.

[20] Tuğrul, B., Artan, İ. Çocukların cinsel eğitimi ile ilgili anne görüsslerinin incelenmesi. Hacettepe Üniversitesi Eğitim Fakültesi Dergisi, 20(20), 2001.

[21] Tuzcuoğlu, N., Tuzcuoğlu, S. Çocuğun cinsel eğitiminde ailelerin karşılaştıkları güçlükler. Eğitim Bilimleri Dergisi, 8(8), 251-262, 1996.

[22] Yeşilay, T., Altun, S. A. Okul Öncesi Öğretmenlerinin Sınıftaki Öğrencilerinin Mastürbasyon Davranışıyla Baş 
Etme Stratejileri. İlköğretim Online, 8(2), 2009.

[23] Yıldırım, A. Şimşek, H. Sosyal bilimeler nitel araştırma yöntemleri (9. Esnek Baskı) Seçkin Yayınevi, Ankara, 2013. 